\title{
Obesity and covid-19: a reflection on the relationship between pandemics
}

\author{
Obesidade e a covid-19: uma reflexão sobre a relação entre as pandemias \\ Obesidad y covid-19: una reflexión sobre la relación entre las pandemias
}

\author{
Andressa Bolsoni-Lopes ${ }^{\mathrm{a}}$ \\ Lorena Barros Furieria \\ Maria Isabel Cardoso Alonso-Vale ${ }^{b}$
}

How to cite this article:

Bolsoni-Lopes A, Furieri LB, Alonso-Vale MIC. Obesity and covid-19: a reflection on the relationship between pandemics. Rev Gaúcha Enferm. 2021;42(spe):e20200216 doi: https://doi.org/10.1590/19831447.2021.20200216

\footnotetext{
- Universidade Federal do Espírito Santo (UFES), Centro de Ciências da Saúde, Departamento de Enfermagem. Vitória, Espírito Santo, Brasil.

- Universidade Federal de São Paulo (UNIFESP), Instituto de Ciências Ambientais, Químicas e Farmacêuticas, Departamento de Ciências Biológicas. Diadema, São Paulo, Brasil.
}

\section{ABSTRACT}

Objective: Carry out a reflective analysis on the relationship of obesity as a risk factor for the worsening of COVID-19.

Method: Reflective study, supported by scientific evidence, which contributed to a critical-reflexive construction on the theme "Obesity" in interface with"Covid-19".

Results: This study brought up important reflections for health professionals, researchers and managers, from the beginning of the pandemic, a period in which obesity was not recognized as a risk factor, until the current scenario, in which a series of pathophysiological mechanisms that clinically connect these diseases are being proposed.

Conclusion: Obesity is a risk factor for the worsening of COVID-19, which is contributing to the overload of health services, and which requires differentiated health care, with adjustments in care, pharmacological protocols and commitment to health education in the within the Unified Health System.

Keywords: Obesity. Coronavirus infections. Risk Factors.

\section{RESUMO}

Objetivo: Realizar uma análise reflexiva sobre a relação da obesidade como fator de risco para 0 agravamento dos quadros de COVID-19.

Método: Estudo reflexivo, subsidiado por evidências científicas, que contribuíram para uma construção crítico-reflexiva sobre a temática "Obesidade" em interface à "Covid-19".

Resultados: Este estudo traz à tona reflexões importantes para os profissionais de saúde, pesquisadores e gestores, desde o princípio da pandemia, período no qual a obesidade não era reconhecida como fator de risco, até o cenário atual, no qual uma serie de mecanismos fisiopatológicos que conectam clinicamente essas doenças estão sendo propostos.

Conclusão: A obesidade é um fator de risco para agravamento da COVID-19, que está contribuindo para o congestionamento dos serviços de saúde, e que requer uma assistência de saúde diferenciada, com ajustes de protocolos assistenciais, farmacológicos e empenho na educação em saúde no âmbito do Sistema Único de Saúde.

Palavras-chave: Obesidade. Infecções por coronavírus. Fatores de risco.

\section{RESUMEN}

Objetivo: Realizar un análisis reflexivo sobre la relación de la obesidad como factor de riesgo para el agravamiento de COVID-19.

Método: Estudio reflexivo, sustentado en evidencia científica, que contribuyó a una construcción crítico-reflexiva sobre el tema "Obesidad" en interfaz con"Covid-19".

Resultados: Este estudio trajo reflexiones importantes para los profesionales de la salud, investigadores y gestores, desde el inicio de la pandemia, período en el que la obesidad no fue reconocida como factor de riesgo, hasta el escenario actual, en el que una serie de mecanismos fisiopatológicos que conectan clínicamente estas enfermedades.

Conclusión: la obesidad es un factor de riesgo para el agravamiento del COVID-19, que está contribuyendo a la congestión de los servicios de salud, y que requiere una atención de salud diferenciada, con ajustes en la atención, protocolos farmacológicos y compromiso con la educación en salud en el dentro del Sistema Único de Salud.

Palabras clave: Obesidad. Infecciones por coronavirus. Factores de Riesgo. 


\section{INTRODUCTION}

The COVID-19 pandemic spread rapidly, affecting thousands of people and killing many of them. This condition has been challenging healthcare systems and researchers around the world, an event that we have not seen for 100 years. The disease is caused by infection with the new coronavirus, SARS-CoV-2, which attacks the upper and lower airways, leading to a flu-like condition that can progress to severe acute respiratory syndrome (SARS) ${ }^{(1-2)}$.

Elderly and individuals with underlying diseases, such as cardiovascular and pulmonary diseases and diabetes are most likely to develop severe forms of Covid-19. However, new and alarming data have revealed serious symptoms and even a negative prognosis for obese people $\mathrm{e}^{(1-2)}$.

In this scenario, a reflection emerges on another pandemic, the obesity pandemic, which has grown significantly in the last three decades, reaching more than 650 million people in the world ${ }^{(3)}$. Obesity is a chronic inflammatory disease, caused by increased adipose tissue mass, which affects metabolic homeostasis and thus is a precursor to diseases such as systemic hypertension and type 2 diabetes mellitus, some types of cancer, among others ${ }^{(4)}$.

Encouraged by the growing and solid body of evidence connecting these pandemics, the present study aimed to conduct a reflective analysis on the relationship between obesity as a risk factor with the worsening of COVID-19, describing the pathophysiological mechanisms involved, especially those exacerbated by obesity in SARs-Cov2 infection.

\section{METHODOLOGY}

Reflective study carried out in May 2020, supported by national and international scientific evidence, whose descriptors "obesity" and "Covid-19", and in English "Obesity" and "COVID-19", were reported jointly and by underlying literature on the theme. Based on the theoretical construct obtained, the reasoning and interpretation of the authors of this study were presented, in order to contribute to the critical-reflective construction on the theme "Obesity" in interface with "Covid-19".

\section{RESULTS}

The analysis of the various aspects of the relationship between obesity and COVID-19 pandemics was based on the reading of scientific articles, bringing to light a series of important knowledge and reflections for health professionals, researchers and managers, from the beginning of the pandemic, when obesity was not recognized as a risk factor, until the current scenario, in which a series of pathophysiological mechanisms that clinically connect these diseases are being proposed.

\section{Obesity was initially neglected as a risk factor for COVID-19}

The relationship between obesity and SARS-CoV-2 was not initially documented in clinical reports from China, Italy or the United States of America (USA) (2,5).

Surprisingly, body mass index (BMI) was rarely recorded or mentioned in the medical records of patients affected by COVID-19, although diseases associated with an increased risk of morbidity and mortality from this new infection, such as heart disease, diabetes and respiratory problems, are also comorbidities of obesity ${ }^{(1-2)}$.

Likewise, previous experiences that detected the close correlation between obesity and complications from viral infections, both for the influenza virus and for other types of coronavirus, which caused widespread infections (SARS, MERS, respectively) were not considered ${ }^{(6)}$. A study conducted in 2009 in the US showed that $67 \%$ of critically ill patients with $\mathrm{H} 1 \mathrm{~N} 1$ had class III obesity $\left(\mathrm{BMl} \geq 40 \mathrm{~kg} / \mathrm{m}^{2}\right)^{(7)}$.

Thus, the increasing prevalence of obesity and previous evidence of the impact of obesity on documented mortality by H1N1 influenza should warn health professionals who care for patients with obesity and COVID-19 of the need for a more effective treatment and greater care to this population. In addition to the previous evidence, other studies have also correlated obesity and COVID-19(5,8).

\section{Obesity is an independent risk factor for COVID-19 morbidity and mortality}

Disturbing international data showed a high prevalence of obesity in critically ill patients with SARS-CoV-2 in intensive care ${ }^{(8-10)}$. In the UK, this prevalence was $72 \%{ }^{(9)}$. In Brazil, obesity is the main comorbidity associated with deaths in people under 60 years ${ }^{(11)}$.

The risk of health problems and death from COVID-19 is up to four times higher in obese individuals ${ }^{(8-10)}$. A study carried out by Simonnet and collaborators in 2020 showed that $85 \%$ of patients with $\mathrm{BMI} \geq 40 \mathrm{~kg} / \mathrm{m}^{2}$ affected by SARS$\mathrm{CoV}-2$ required invasive mechanical ventilation, while only $47 \%$ of those with BMI below $25 \mathrm{~kg} / \mathrm{m}^{2}$ had such need ${ }^{(8)}$.

The referred studies showed that of COVID-19 severity is directly associated with increased BMI, and that obesity is a risk factor for morbidity and mortality due to SARSCoV-2 infection, regardless of the association or not with other comorbidities ${ }^{(8-10)}$. 
If obesity is a predictor of poor prognosis or complications for COVID-19, therapeutic actions aimed at reducing the chronic inflammatory state generated by obesity and at restoring body metabolic homeostasis should be considered, in order to reduce the impact of obesity on SARS-COV-2 infection.

\section{The pathophysiological mechanisms involved in the association between obesity and severe cases of COVID-19}

SARS-CoV-2 infects humans through the upper airways and invades cells that express the angiotensin-converting enzyme 2 (ACE2) in their membranes, such as lung, heart, adipose, renal and gastrointestinal cells. This leads to an intense inflammatory state, described as a "cytokine storm", mediated especially by IL-6 $6^{(12)}$.

The mechanism of acute lung injury and cardiovascular damage is said to be largely mediated by the activation of the renin-angiotensin system and greater bioavailability of angiotensin II, which is a molecule known for its inflammatory, vasoconstrictive, hypertensive and oxidative effects. The virus reduces the number of sites available for binding angiotensin II to ACE2, thereby reducing its conversion to angiotensin 1-7, which has an anti-inflammatory and vasodilatory action ${ }^{(12)}$.
The understanding of the pathophysiological mechanisms that connect obesity and COVID-19 by health professionals is crucial to ensure adequate care. Therefore, one must know that the adipose tissue, in addition to storing energy of mammals, is the regulatory center for body metabolism and an endocrine organ that produces hormones, adipokines and cytokines ${ }^{(4)}$.

Figure 1 summarizes the recently described different mechanisms through which obesity would contribute to the worsening of SARs-COV2 infection, namely: amplification of the state of inflammation, damage to the respiratory and cardiovascular systems and glucose metabolism, favoring thrombus formation and dysregulation of the immune system ${ }^{(6,9,13-14)}$.

The severe exacerbation of the inflammatory state in obesity is caused by the intense secretion, by the adipose tissue, of adipokines and pro-inflammatory cytokines such as IL- 6 and TNF-alpha, in addition to the infiltration of cells of the immune system ${ }^{(4,9)}$.

Moreover, the human adipose tissue has its own renin angiotensin system and expression of ACE and ACE2. The interaction between adipose tissue, SARS-CoV-2 and ACE2/ angiotensin II, may also explain cardiovascular damage and the strong inflammation that increases the risk of morbidity and mortality in obese patients with COVID-19(9,12,14).

\section{How does obesity contribute to the severity of Covid 19 cases?}

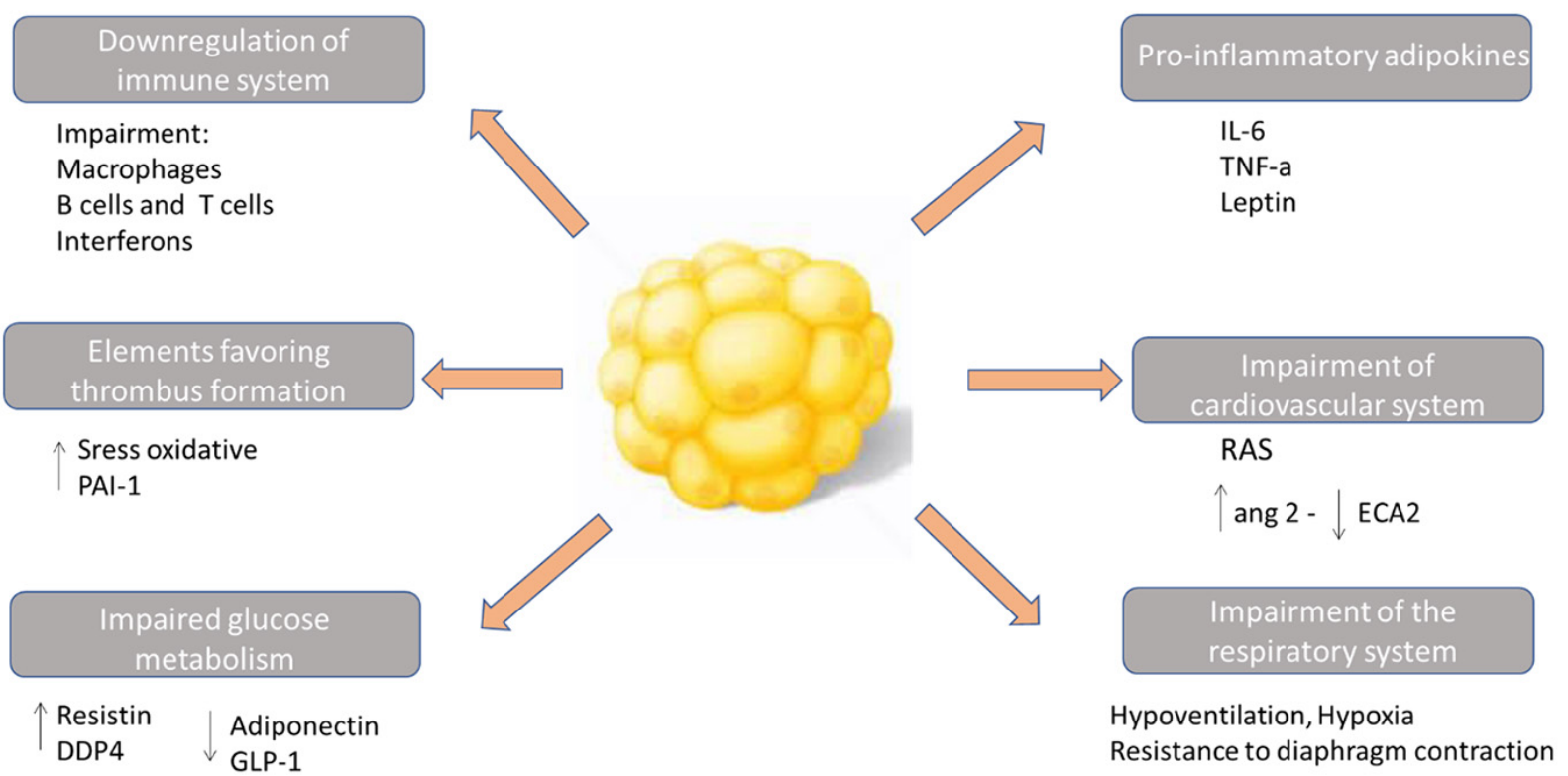

Figure 1 - Pathophysiological mechanisms that explain the worsening of cases of COVID-19 in obese patients Source: Authors, 2020.

Notes: Ang2, angiotensin 2; DDP4, dipeptidyl peptidase 4; ACE2, angiotensin-converting enzyme 2; GLP-1, glucagon-like peptide 1; IL-6, interleukin 6; PAl-1, type 1 plasminogen activator inhibitor; TNF-a, tumor necrosis factor alpha. 
Obesity, alone, carries a greater risk of thrombus formation, due to the increased production of type 1 plasminogen activator inhibitor (PAI-1) and oxidative stress. This clinical condition deserves special attention due to the association between COVID-19, disseminated intravascular coagulation and high rates of venous thromboembolism ${ }^{(4,9)}$.

In addition to cardiovascular and thrombotic comorbidities, obese people have lower functional capacity and complacency of the respiratory system, diaphragmatic excursion and in hypoventilation, which, associated with pulmonary infection, exacerbate the pre-existing hypoxia ${ }^{(14)}$.

The significant metabolic complications in obese patients should also be stressed. Excess body fat, especially visceral fat, impairs glucose uptake, insulin resistance and reduced pancreatic beta cell function, making an appropriate metabolic response difficult, and this is essential in a disease that impacts immune response, as it is the case of severe infections. The SARS-CoV-2 virus can also directly affect the function of pancreatic beta cells, due to its interaction with ACE2 ${ }^{(14)}$. Another association between the referred conditions that impairs glucose metabolism is the increase in dipeptidyl peptidase 4 (DPP-4), an enzyme with a hyperglycemic effect, which inhibits GLP-1 ${ }^{(9)}$.

Finally, individuals with excess body weight develop a higher viral load and need more time to resolve infectious processes because of the reduced innate and acquired immune response. There is less action of phagocytosis by macrophages, delay in antigen presentation and development of antibodies, lower activity of $\mathrm{T}$ and $\mathrm{B}$ lymphocytes and reduced production of interferons $s^{(6,14)}$.

Taken together, the disorders associated to obesity increase the risk of infection and its complications in the individuals, who can also transmit the virus for a longer period compared to the general population. Health teams should reflect on these data and consider the need for longer quarantine periods for obese people with COVID19 than the one recommended for all other patients.

\section{What are the implications of these studies for health professionals, public health managers and researchers?}

Obesity is a modifiable risk factor and reducing its incidence will contribute to the reduction of severe cases of COVID-19 and of so many other existing and future infectious and chronic diseases.

Based on this clinical evidence available in the scientific literature, health professionals perceive the need to look more closely at this population, considering their individual needs for adjustments to care protocols, in order to prevent and minimize serious cases of COVID-19 in obese individuals.
What is most distressing is the fact that obesity is increasing the number of deaths due to COVID-19. This population must avoid any contamination by SARS-CoV-2, taking as much care as possible, through the adoption of preventive measures, and, once they are contaminated, they must be monitored as soon as possible by health professionals and for longer than individuals with $\mathrm{BMI} \leq 25$ $\mathrm{Kg} / \mathrm{m}^{2}$ or eutrophic.

For researchers, the association between obesity and severe cases of COVID19 should support the construction of instruments for risk assessment or investigation, considering $\mathrm{BMI}$ and waist circumference. New therapeutic interventions should be investigated to reduce the chances of the individuals developing the severe form of COVID-19, focusing on adipose tissue, such as weight-loss drugs and medications for treating the inflammatory state associated to obesity, in addition to appropriate diets. Studies on the validation of clinical protocols targeted at obese patients are also needed.

Regarding public health, given all the severity factors for COVID-19, it is necessary to understand that obesity is a modifiable risk factor. Therefore, lifestyle changes must be strongly encouraged, aiming to reduce the risks of these diseases and of so many others associated with obesity. Creating strategies to educate the population on healthy eating and physical exercise should be a priority among public health policies. Obviously, this is a challenge, especially in the face of the current economic crisis, as it involves social and cultural changes in the population.

It is also necessary to understand obesity as a disease, and not merely as an aesthetic standard, and that as such, it requires multidisciplinary care, a strong commitment to health education, drugs, and surgeries available under the Unified Health System.

\section{CONCLUSION}

Obesity was recognized, although belatedly, as a risk factor for the worsening of infection by the new coronavirus. The severe cases of COVID-19, the demand for intensive care beds and for invasive mechanical ventilation are directly related to high BMI $\left(\geq 30 \mathrm{Kg} / \mathrm{m}^{2}\right)$. Therefore, the obesity pandemic is contributing to the overload of health services, since it is associated with the worsening of cases of COVID-19.

Some of the pathophysiological mechanisms of the relationship between obesity and COVID-19 have already been suggested, including: state of inflammation, damage to the respiratory and cardiovascular systems, thrombus formation and dysregulation of metabolism and the immune system. Therefore, additional research on this theme is necessary to guide ae care practice based on evidence and clinical health protocols. 


\section{REFERENCES}

1. Zhou F, Yu T, Du R, Fan G, Liu Y, Liu Z, et al: Clinical course and risk factors for mortality of adult inpatients with COVID19 in Wuhan, China: a retrospective cohort study. Lancet. 2020;395(10229):1054-62. doi: https://doi.org/10.1016/ S0140-6736(20)30566-3

2. Yang J, Zheng Y, GouX, Pu K, Chen Z, Guo Q, et al. Prevalence of comorbidities and its effects in coronavirus disease 2019 patients: a systematic review and meta-analysis. Int J Infect Dis. 2020;94:91-5. doi: https://doi.org/10.1016/j.ijid.2020.03.017

3. World Health Organization (CH) [Internet]. Genebra: WHO, c2020 [cited 2020 Jun 02]. Obesity and overweight; [about 1 screen]. Available from: https:// www.who.int/news-room/fact-sheets/detail/obesity-and-overweight

4. Chait $A$, den Hartigh LJ. Adipose tissue distribution, inflammation and its metabolic consequences, including diabetes and cardiovascular disease. Front Cardiovasc Med. 2020;7:22. doi: https://doi.org/10.3389/fcvm.2020.00022

5. Dietz W, Santos-Burgoa C. Obesity and its implications for COVID-19 mortality. Obesity (Silver Spring). 2020;28(6):1005. doi: https://doi.org/10.1002/ oby. 22818

6. Luzi L, Radaelli MG. Influenza and obesity: its odd relationship and the lessons for COVID-19 pandemic. Acta Diabetol. 2020;57(6):759-64. doi: https://doi. org/10.1007/s00592-020-01522-8

7. Louie JK, Acosta M, Winter K, Jean C, Gavali S, Schechter R, et al. Factors associated with death or hospitalization due to pandemic 2009 influenza A(H1N1) infection in California. JAMA. 2009;302(17):1896-902. doi: https:// doi.org/10.1001/jama.2009.1583

\section{- Authorship contribution:}

Conceptualization: Andressa Bolsoni-Lopes; Lorena Barros Furieri.

Methodology: Andressa Bolsoni-Lopes; Lorena Barros Furieri.

Visualization: Andressa Bolsoni-Lopes; Lorena Barros Furieri; Maria Isabel Alonso-Vale.

Writing - original draft preparation: Andressa BolsoniLopes; Lorena Barros Furieri; Maria Isabel Alonso-Vale.

Writing - review and editing: Andressa Bolsoni-Lopes; Lorena Barros Furieri; Maria Isabel Alonso-Vale.

\section{- Corresponding author:}

Andressa Bolsoni-Lopes

Email: andressa.lopes@ufes.br
8. Simonnet A, Chetboun M, Poissy J, Raverdy V, Noulette J, Duhamel A, et al. High prevalence of obesity in severe acute respiratory syndrome coronavirus-2 (SARS-CoV-2) requiring invasive mechanical ventilation. Obesity (Silver Spring). 2020;28(7):1195-9. doi: https://doi.org/10.1002/ oby.22831

9. Malavazos AE, Romanelli MMC, Bandera F, lacobellis G. Targeting the adipose tissue in COVID-19. Obesity (Silver Spring). 2020;28(7):1178-9. doi: https:// doi.org/10.1002/oby.22844

10. Lighter J, Phillips M, Hochman S, Sterling S, Johnson D, Francois F, et al. Obesity in patients younger than 60 years is a risk factor for Covid-19 hospital admission. Clin Infect Dis. 2020;71(15):896-7. doi: https://doi.org/10.1093/ cid/ciaa415

11. Bol Epidemiol Esp COE-COVID 19. 2020 [cited 2020 Jun 02];(16):1-67. Available from: https://portalarquivos.saude.gov.br/images/pdf/2020/May/21/202005-19---BEE16---Boletim-do-COE-13h.pdf

12. Rothan HA, Byrareddy SN. The epidemiology and pathogenesis of coronavirus disease (COVID-19) outbreak. J Autoimmun. 2020;109:102433. doi: https:// doi.org/10.1016/j.jaut.2020.102433

13. Petrakis D, Margină D, Tsarouhas K, Tekos F, Stan M, Nikitovic D, et al. Obesity - a risk factor for increased COVID-19 prevalence, severity and lethality (Review). Mol Med Rep. 2020;22(1):9-19. doi: https://doi.org/10.3892/ mmr.2020.11127

14. Sattar N, McInnes IB, McMurray JJV. Obesity a risk factor for severe COVID-19 infection: multiple potential mechanisms. Circulation. 2020;142(1):4-6. doi: https://doi.org/10.1161/CIRCULATIONAHA.120.047659

\section{Associate editor:}

Dagmar Elaine Kaiser

Received: 06.04.2020

Approved: 09.09.2020
Editor-in-chief:

Maria da Graça Oliveira Crossetti 


\section{Erratum of article:}

Bolsoni-Lopes A, Furieri LB, Alonso-Vale MIC. Obesity and covid-19: a reflection on the relationship between pandemics. Rev Gaúcha Enferm. 2021;42(spe):e20200216. doi: https://doi.org/10.1590/1983-1447.2021.20200216

\section{On page 1, Authors:}

\section{where it reads:}

Lorena Furieri

\section{should read:}

Lorena Barros Furieri

\section{On page 5, Authorship contribution:}

\section{where it reads:}

Conceptualization: Andressa Bolsoni-Lopes; Lorena Furieri.

Methodology: Andressa Bolsoni-Lopes; Lorena Furieri.

Visualization: Andressa Bolsoni-Lopes; Lorena Furieri; Maria Isabel Alonso-Vale.

Writing - original draft preparation: Andressa Bolsoni-Lopes; Lorena Furieri; Maria Isabel Alonso-Vale.

Writing - review and editing: Andressa Bolsoni-Lopes; Lorena Furieri; Maria Isabel Alonso-Vale.

\section{should read:}

Conceptualization: Andressa Bolsoni-Lopes; Lorena Barros Furieri.

Methodology: Andressa Bolsoni-Lopes; Lorena Barros Furieri.

Visualization: Andressa Bolsoni-Lopes; Lorena Barros Furieri; Maria Isabel Alonso-Vale.

Writing - original draft preparation: Andressa Bolsoni-Lopes; Lorena Barros Furieri; Maria Isabel Alonso-Vale.

Writing - review and editing: Andressa Bolsoni-Lopes; Lorena Barros Furieri; Maria Isabel Alonso-Vale. 